CRETACEOUS DEPOSITS OF THE SIOUX VALLEY. BY

HARRY FOSTER BAIN. 


\title{
CRETACEOUS DEPOSITS OF THE SIOUX VALLEY.
}

\author{
BY HARRY FOSTER BAIN.
}

The Cretaceous formations of the upper Missouri region have long attracted attention. As early as 1839 the rocks at the mouth of the Sioux river, near the site of the eity of the same name, were examined by the French explorer Nicollet. Since that time the locality has been visited by a number of workers and by them has been made the starting point for all geological investigations in the region. While the knowledge regarding the beds along the Missouri river has become quite complete, information pertaining to exposures along the various tributaries has been almost wholly neglected. Along the Sioux river, which forms the northern third of the western boundary of Iowa, the formations have received no notice except that which has been merely incidental to the examinations of more western districts.

In prosecuting the recent work it was found advantageous to begin with the well-known outcrops at Sargeant bluff and Sioux City. The Cretaceous exposures, however, begin some distance further down the Missouri river, so that the section of the Cretaceons made is not complete for the entire western border of the state. There are at least 100 to 200 feet of strata referable to this age which are below the horizon taken as the base line in the present connection. 
The difficulties attending the study of the rocks of northwestern Iowa arise from two sources. In the first place the various members of the Cretaceous of this region are very slightly indurated. The second difficulty is caused by the great thickness of the drift throughout the region: On account of the softness of all the materials, exposures made by streams are more rapidly obscured than ordinarily and the stratigraphical details are not easily made out after a short period. On the other hand there has been produced topographical effects of wonderful beauty and variety. .

From Sargeant bluff to a considerable distance beyond Sioux City the hills are made up almost entirely of loess, the Cretaceous beds being exposed only a few feet above the river level. The loess of this region is the typical, fine, homogeneous material retaining its usual characteristic topography. It is marked by picturesque bluffs from which single points stand out as isolated peaks 150 to 300 feet above the water level. North of Sioux City the bluffs on the east side of the Sioux river rise from the water's edge. On the opposite side of the stream as far up as Westfield there is a broad level plain which stretches away westward to the Missouri. The level bottom land in Dakota spreads out between the two rivers for a distance of twelve to fourteen miles. Beyond is the low fringe of green timber marking the course of the Missouri and back of this again rise the high bluffs on the Nebraska side of the stream, too far away to be distinguished except in the clearest weather.

About two miles below Westfield low rounded drift hills appear on the west border of the Sioux and it is here that the Sioux valley proper opens into that of the Missouri. From this point down to its mouth the former 
stream flows across the flood plain of the latter, the one keeping close to the eastern edge, while the channel of the other is well towards the opposite side. In this portion of its course the Pleistocene deposits along the Sioux river are very largely loess. North of Westfield the latter becomes less conspicuous.

The drift hills of the Sioux valley proper, from Westfield to Hawarden, have low rounded outlines. From the latter point to Granite station gravel beds become more prominent, forming a series of terraces which are usually well marked and extend along the river for miles. The basal beds of the drift at this place are made up almost entirely of large rough boulders of considerable variety, yet in the main derived from the Sioux quartzite. In size they range from ten feet in diameter down to the smallest pebbles. There is a more or less complete stratification noticeable in their arrangement. At Granite, the first exposure of Sioux quartzite is encountered in place. Two miles to the north the river cuts throngh ledges of this rock forming the most southerly of the gorges which mark a considerable portion of its course.

The large number of excellent exposures in this region allows the order and general succession of the rocks to be made out with considerable detail. The structure is at no point very complex. The beds have

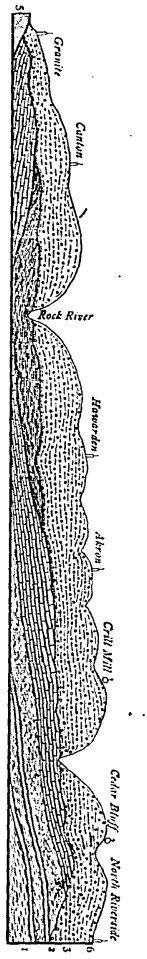




\section{CRETACEOUS DEPOSITS OF THE SIOUX VALLEY.}

been practically undisturbed and apparently have now nearly the same inclination as when originally deposited, with a gentle slope seaward, in this case to the northwest. In a few places low anticlines and broad, shallow synclinal troughs are noticed.

It has recently been shown by Calvin* that the Cretaceous beds of northwestern Iowa contain the record of continuous subsidence; that the different formations were in fact laid down, in part at least, contemporaneously, the more open sea depositions gradually encroaching farther and farther inland and overlapping the more strictly littoral deposits as the shore sank beneath the invading waters.

In working up the Sioux river from its mouth, the rocks are seen to have a slight dip to the north. ' From Sioux City to Hawarden the different beds pass successively below the water level. From Hawarden to Canton only a few outcrops are seen, and the interval seems to represent a low syncline. At the latter point the Niobrara again appears, followed soon by the Sioux quartzite, the beds which further southward lie immediately below the chalks being here apparently absent. The general relations of the formations are represented in Figure 1, which is a section along the Sioux river from Sioux City northward to the state line. Number 1 is the Dakota, with two sandstone bands at the top; 2 is the Benton shale; 3 , the Niobrara chalks ; 4 , the Pierre shale in the trongh with Rock river in the middle; 5 is the Sioux quartzite; 6 is the drift and loess mantle.

At North Riverside the section exposed is as follows :

* Cretaceous Deposits of Voodbury and Plymouth Counties: Iowa Geol. Sur., vol. J, First Ann. Rep., pp. 147-161. Des Moines, 1893 . 


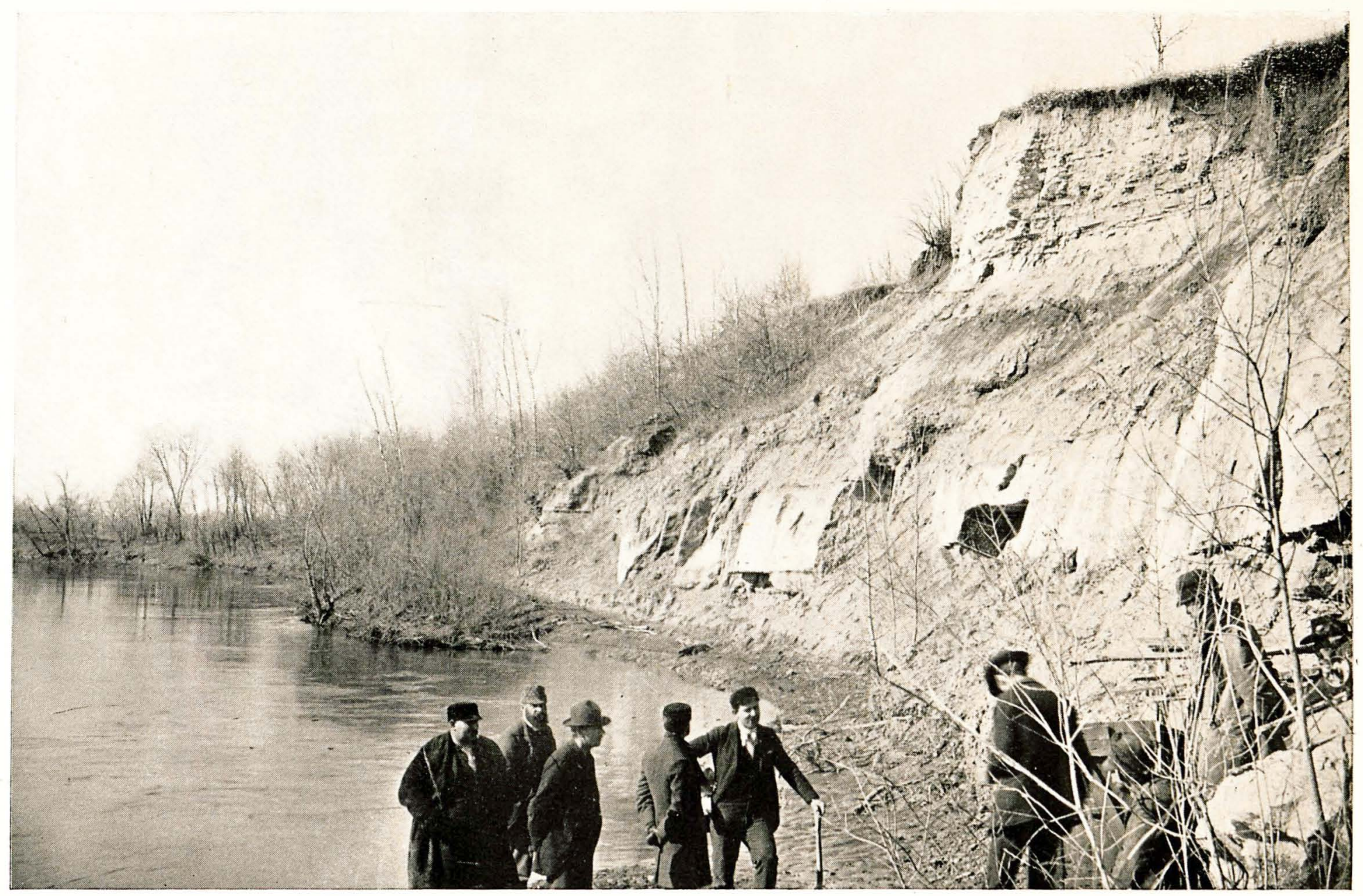

DAKOTA AND BENTON FORMATIONS ON THE SIOUX RIVER. WESTFIELD. 
. 
7. Loess

FEET.

30

6. Sandstone, calcareous, white, fine-grained, shaly in part, with abundant characteristic plants....... I5

5. Shale, variegated in color, with streaks of sand.... $2 \mathrm{~S}$

4. Lignite, impure...................... 1/2

3. Shale, clayey, variable, with bands of ferruginous nodules.$\ldots \ldots \ldots \ldots \ldots \ldots \ldots \ldots \ldots \ldots \ldots$,

2. Sandstone, coarse-grained, orange to red in color, containing quartzitic concretions. ............. 10

I. Shale, clayey, dark gray to drab in color....... I2

Further north these strata pass successively beneath the river until at the Crill mill only the upper sandstone (number 6) is seen. The section at this point, which is one of the most instructive now exposed above the water level, is as follows:

FEET.

5. Drift $\ldots \ldots \ldots \ldots \ldots \ldots \ldots \ldots \ldots \ldots \ldots \ldots \ldots \ldots \ldots, 5^{0}$

4. Limestone, chalky ....................... 12

3. Shale, dark blue to drab, sandy in places......... 5o

2. Sandstone, fine-grained, calcareous, light buff to

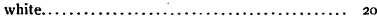

I: Lignite (exposed )........................ $11 \frac{2}{2}$

A short distance above the point mentioned the sandstone (number 2) passes beneath the level of the river. The drab shales persist with frequent outcrops some twelve miles farther. The chalky limestone (number 4 ) continues to be exposed at intervals to the north.

Within three miles of Hawarden the chalk rock becomes covered at one point by a later deposit. The section exposed is :

FEET.

3 Drift.................................. 35

2. Shale, drab to blue, argillaceous, sandy in part, containing selenite crystals ................ 25

1. Limestone, fossiliferous, thin-bedded, with chalky partings $\ldots \ldots \ldots \ldots \ldots \ldots \ldots \ldots \ldots \ldots \ldots \ldots \ldots, 20$

In the extreme north western corner of Iowa the Sioux quartzite rises above the water level of the river. While 
106 CRETACEOUS DEPOSITS OF 'THE SIOUX VALLEY.

no actual juncture between any of the Cretaceous beds and this rock have been observed within the limits of Iowa, a number of exposures in adjoining portions of South Dakota show that it is covered in part, at least, by the chalk rock of the preceding section.

Meek and IIayden, in their studies of the Cretaceous in the upper Missouri region, differentiated five formations ${ }^{*}$ :

5. Fox Hills, sandstones and arenaceous shales.

4. Fort Pierre, blue, argillaceous shales.

3. Niobrara, chalks and limestones.

2. Fort Benton, variegated shales.

1. Dakota, sandstones.

The lowest member, the Dakota, has been recognized over a wide extent of territory, and is commonly regarded as the basal member of the Cretaceous in the upper Missouri region. To it the rocks in the neighborhood of Sioux City were early referred. While in the main the differences between the Dakota and Fort Benton are well marked, a gradation between them has been frequently noted, especially in the more eastern portions of its limits. This transition is so notable in Iowa that White grouped the two together under the name Woodbury shales and sandstones. The difficulties encountered in separating the formations were also clearly recognized by Hayden. The general utility, however, of the division has not been doubted. While there is no well marked physical break between the Dakota and Fort Benton formations, they are as a rule sharply contrasted, and at numerous points a well defined line of separation may be recognized. In Iowa the relative thinness of the beds make the separation

*U. S. Geol. Sur. Terr., vol. IX, pp. xxiv-xxy. Washington, IS76. 
of less value stratigraphicully than elsewhere, though it may still be recognized.

The Dakota, as developed in Iowa, consists of sandstones, clayey and sandy shales and may on the whole be characterized as prevailingly arenaceous as contrasted with the overlying argillaceons beds. Described more particularly the Dakota contains certain well marked sandstones, in part calcareous, fine-grained, white or buff in color, and in part drab, coarse-grained, ferruginous, assuming in places quartzitic facies, complex beds of clay and clay shales of variable color and texture, sandy shales and thin beds of lignite and coal of difterent degrees of purity.

At the well-known outcrop at Sargeant bluff, seven miles below Sioux City, there is exposed :

5. Loess, thickening back from the river and forming bold bluffs 100 to 150 feet high................ to

4. Sandstone, fine-grained, light buff to white above, coarse, orange-yellow below................ 25

3. Lignite, more or less earthy, usually of a dark purp-

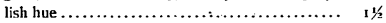

2. Shale, variegated, brilliant orange to dark olive green, with interstratified beds of fine white sand and thin bands of ferruginous concretions containing plant remains........................ 18

I. Shale, sandy, reddish, becoming drab to orange below; and containing large ferruginous sandy masses with plant remains.

FEET.

\author{
40
}

At the foot of Prospect hill in Sioux City is another exposure of Dakota, where two sandstones are seen separated by shale :

3. Sandstone, dark yellow, coarse-grained, with ferruginous concretions................... so

2. Shale, clayey, dark blue to drab........... 12

I. Sandstone, fine-grained, homogeneous, white.... 20 


\section{CRETACEOUS DEPOSITS OF THE SIOUX VALLEY.}

Probably the best of the exposures examined in this vicinity is the one at Riverside already given. North of this point the lower sandstone (number 2 ) splits up and becomes shaly. It also thickens considerably and merges more or less with the underlying shales. At the Reese "granite" quarry it exhibits an interesting quartzitic facies. A portion of the sandstone has become indurated and forms a hard, steelgray layer with a thickness of four feet.

At Cedar bluff is a good exposure which has been frequently described. The beds seen here are as follows :

\footnotetext{
FEET.

9. Loess................................ 50

8. Limestone, thinly bedded, exposed in slope above.. 20

7. Shale, buff, sandy, with layers of sandstone one to two inches thick, and ferruginous concretions.... 25

6. Shale, drab to dark blue; fine-grained, argillaceous. 28

5. Sand and lignite mixed...................... $11 / 2$

4. Sandstone, white, calcareous, loosely consolidated. 8

3. Shale, argillaceous, sandy in part, drab to blue.... 12

2. Sandstone, white to orange, coarse-grained, with ferruginous concretions.................... 10

I. Shale, variable, largely arenaceous, imperfectly,

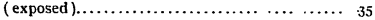

Numbers 1 to 5 inclusive may be referred to the Dakota, 6 and 7 being Benton and 8 Niobrara. North of this place the Dakota is found at successively lower levels until at the old site of the Crill mill only a thin band of lignite and the upper sandstone members are visible. A short distance beyond, the lower member of the Cretaceous passes beneath the level of the river and does not reappear again in Iowa.

The following may be given as a general section of the Dakota as found in the vicinity of Sioux City : 
FEET.

5. Sandstone, fine-grained, calcareous, light buff to white, well characterized by an abundance of plant remains $\ldots \ldots \ldots \ldots \ldots \ldots \ldots \ldots \ldots \ldots \ldots, \ldots \ldots \ldots, 20$

4. Shales, argillaceous, arenaceous in part, very variable in color,and texture, containing thin beds of impure lignite and bands of ferruginous nodules.. 50

3. Sandstone, coarse-grained, shaly in part, with a quartzitic facies; variable in thickness........ to to 30

2. Shale, argillaceous, dark gray to drab.......... 12

t. Sandstone, fine, white, homogeneous ........... 20

Sandstone number 1 is seen at the foot of Prospect hill, and above it at this same place is shale number 2 , believed to be the same as the one seen at the base of the pit of the Northwestern Pipe and Tile Works at Riverside. Number 3, appearing first at Prospect bill, is well characterized at North Riverside, and becomes quite prominent from there to Cedar bluff, at which place it has become divided and assumed a shaly character. Beyond, it thins out considerably and soon passes below the water level. Number 4 is the most prominent bed of the entire formation. It is exposed at Sargeant bluff, is prominent at North Riverside, and the lignite at the base of the Crill mill section is believed to belong to it. Number 5 is considered the uppermost member of the Dakota group. It is seen caping the section at Sargeant bluff, is at the top of the Riverside section, appears at Cedar bluff and at the base of the Crill mill exposure.

The relations between the Dakota and Benton are, perhaps, most sharply defined at the Crill mill. Here the upper sandstone of the Dakota is a massive, quite homogeneous bed, twenty feet thick. Immediately overlying it are strata of undoubted Benton age.

The Benton formation, as defined by Hayden, is a dark gray, laminated, plastic clay containing abundant pyrite concretions and numerous selenite crystals. It is 


\section{CRETACEOUS DEPOSITS OF TIIE SIOUX VALLEY.}

extensively developed along the upper Missouri and in the Black Hills. Its estimated total thickness is 800 feet. In passing down the Missouri river from Pierre it gets successively thinner and thinner, until in Iowa it is represented by a comparatively unimportant bed of shale scarcely fifty feet in thickness. The southern limit of the formation is not well defined. At Cedar bluff, beds 6 and 7 may be referred to it. Calvin gives its most southerly exposure at about four miles below the mouth of Broken Kettle creek. There aire numerous minor exposures near the mouth of that stream. In the Crill mill section the Benton forms the median portion and is quite well exposed. The most northerly exposure known is on the Dakota side about eight miles north of Akron, at the site of the old Otis mill. It is also more or less completely exposed at a number of intermediate points.

The formation is represented by a dark blue to drab shale, slightly arenaceous in places, and somewhat calcareous near the top. Selenite is frequently abundant. The thickness of the beds is about forty feet, though at Crill mill a slightly greater vertical extent seems to be indicated. A number of vertebrate fossils have been found in the shales, and molluscan remains are not uncommon. Inoceramus problematicus, Schlotheim, is especially common ; though this fossil is found occasionally in all the members of the Cretaceous of this region, being most abundant in the Niobrara.

The close relations existing between the Benton and the Niobrara are everywhere noticeable. The upper portion of the former becomes gradually more calcareous, thin bands of limestone divide the shale, and the fossils of the superior member appear. These facts, which have 


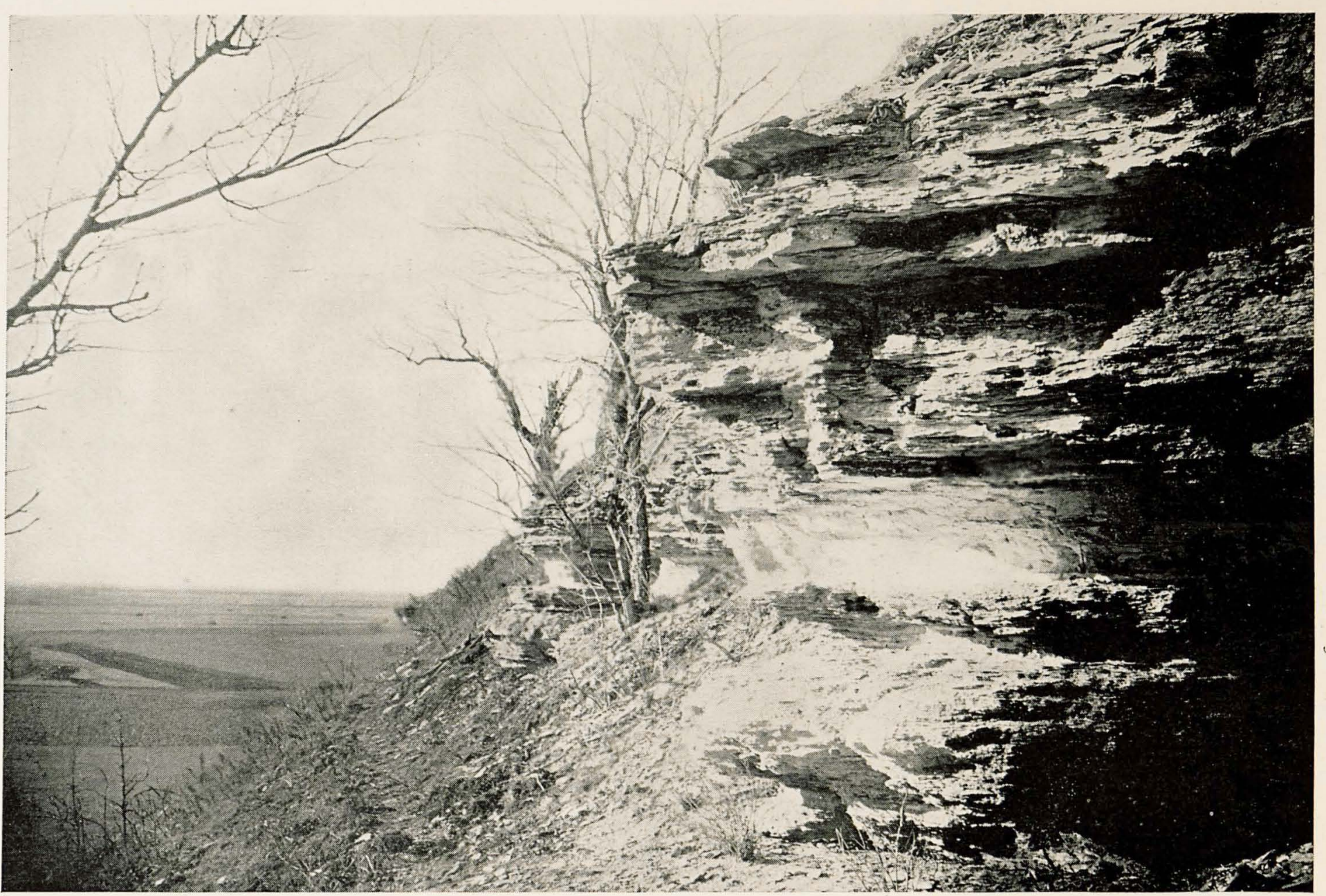



been widely noticed, has led to the grouping of the two formations under the name Colorado, as proposed by King.

The Niobrara division has probably a wider geographic distribution in Iowa than any other of the Cretaceous deposits. It is also the most constant in lithological features and is characterized by numerous species of fossils, so that its recognition is easy and secure. A general section of this member is :

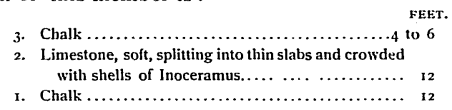

On the west side of the Missouri these beds extend for a distance of nearly thirty miles below Sioux City, though in Iowa they have not been recognized much below the northern boundary of Woodbury county. They are known to extend as far east as Sac county. They are exposed in the slope above the top of Cedar bluff and in the section at Crill mill. In the neighborhood of Westfield the Niobrara forms the major portion of the hills. An exposure immediately beyond Akron shows a thickness of twenty feet or more, and three miles below Hawarden it is again seen. Beyond the last named point the beds apparently pass below the river level and are not seen again until Canton, South Dakota, is reached. At this point the chalk rock was formerly quarried and used for building purposes. The superposition of the Niobrara on the Sionx quartzite is shown at a number of places near Carson, South Dakota, about five miles north of the Iowa line, where a thickness of fifteen feet of Niobrara strata is seen overlying the quartzite.

At all the exposures just mentioned, as well as a large number of others in adjoining regions, the Niobrara 
presents similar lithological charneters. It is composed of varying proportions of chalk and limestone. The former is soft, white to bufl' in color, more or less fossiliferons, and while in places quite free from limestone for several feet, in others it is interbedded with it. The limestone is also soft, very fossiliferous, and quite thinly bedded. The different layers of limestone are separated by thin beds of chalk usually from one and one-half to ten inches in thickness.

Beds referable to the Pierre are exposed about three miles south of Hawarden, in Sioux county ( $\mathrm{T}_{\mathrm{p} .94 \mathrm{~N}}$., R. XLVIII W., Sec. 15). At this place the river makes a sharp bend and washes the face of a high bluff. The Chicago, Milwaukee and St. Paul railway has been built along the base of this bluff, which is at one place cut by a small ravine. The following section is exposed :

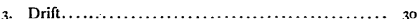

2. Shale, drab to blue, argillaceous, sandy in part, with numerous selenite crystals.................. 25

1. Limestone, fossiliferous, thinly bedded, with chalky layers ............................... 20

The lower portion (number 1) is manifestly Niobrara. It exhibits all the lithological characters which distinguish that formation in this region, and contains many of its most characteristic fossils. The shale which lies above the chalk is fine, drab, argillaceous, rather unctuous, contains some carbonaceous matter, balls of pyrite, thin veins of gypsum and much selenite. The latter usually occurs as small rosettes in the clay, though well formed erystals are not uncommon. The deposit is quite homogeneous, being to all appearances of the same character throughout its entire thickness. It is finely fissile, splitting easily though not sharply along the bedding planes. It is firm at first but crumbles under weathering influences, though 
maintaining an abrupt face in exposures. Along planes of division sand is not uncommon, though always in small quantities.

In all its lithological characters the Hawarden beds agree closely with the description given by Meek of the lower member of the Pierre formation as occurring throughout the upper Missouri region. There is little upon which to base a paleontological correlation. The fossils occurring in the Hawarden beds are rare and very imperfectly preserved. No species can be recognized. This is, however, itself evidence of the correctness of the correlation as the lowermost portion of the Pierre is characteristically non-fossiliferous. The general geological relations of the region bear out the probability of the Pierre age for the Hawarden beds. The same shales have recently been opened up at Caliope, and are there used in the manufacture of brick. The beds are exposed near the mouth of Rock river and extend up that stream some distance. Clays and shales, probably belonging to the same series, are also exposed near Canton, South Dakota. The earliest indication of the presence of Cretaceous in the upper Missouri region is found in the account of the Lewis and Clarke expedition to the northwest. Both Nuttal and Long also collected fossils from this region; and in 1832 the Prince Neuwied obtained Cretaceons types from below Fort Pierre. Nicollet, ${ }^{*}$ in 1839, noticed the presence of Cretaceous in Iowa, and seems to have recognized the Pierre beds farther up the Missouri, though apparently confusing some of the other members of the series. In 1849, Evans, $\uparrow$ one of Owen's assistants, visited the region and collected Inoceramus crispi and other forms from the Pierre beds. No attempt, however, seems to have been made to construct a section of the rocks showing

* Sen. Doc., 26 Cong., and Sess., vol. II, No. 237. I8.1.

t Geol. Sur. WVis., Iowa, Minn., p. $195 .{ }_{1852}$.

8 G. Rep. 


\section{CRETACEOUS DEPOSITS OF THE SIOUX VALLEY.}

the relations of the different strata in the varions localities. The first published section of the Cretaceous beds of the upper Missouri appears to have been that given by Meek," in 1856. In this section five members of the Cretaceous were recognized and numbered. Though number 4 of this series corresponds essentially to the Pierre, it was not given this name until 1861. $\dagger$ It was then recognized as being developed principally in the Bad Lands, at the Great Bend of the Missouri, and extending down that river to near Bijou hill ten miles below the mouth of White river, where the lowest member was exposed. Haydent mentioned its occurrence in the hills near the mouth of the Niobrara, and Calvin \| refers the dark beds of shale capping the Niobrara bluffs at Yankton to this age. This has been regarded as the eastern limit of the Pierre, and is forty-five miles southwest of Hawarden. It is significant that Meek, in deseribing the lower portion of the Pierre, uses these words: "This bed usually occupies depressions in the previously eroded upper surface of the formations beneath." $\$$ This observation, taken in connection with the distance from the other outcrops and certain indications of unconformity seen at Hawarden, lead to the conclusion that the Hawarden beds may constitute an outlier. It seems probable that it covers but a comparatively small area and constitutes a remnant of a larger body now removed through erosion. The extension eastward of the Pierre limits, the recent discovery of Niobrara in Sac county, Iowa, the marked Fox Hills aspect of certain fossils discovered by White I in 1873 renders it very probable that the Mesozoic seas spread much farther eastward than has hitherto been commonly recognized.

* Mem. Am. Acad. Arts and Sci., vol. V, 405.1856.

† Proc. Acad. Nat. Sci., Phila., vol. XIII, p. 419 . I86I.

\pm U. S Geol. and Geog. Sur. Terr., First Ann. Rep., pp. 54-55. 1873.

il. Proc. lowa Acad. Sci., vol. I, pt. iii, p. I2. 1893 .

Proc. Acad. Nat. Sci., Phila., vol. XIII, p. $424 .{ }_{1861}$

if Am. Ad. As. Sci., vol. XXI, pp. 187-192. Cambridge, 1873 . 